Print ISSN: 2288-4637 / Online ISSN 2288-4645

doi:10.13106/jafeb.2020.vol7.no7.073

\title{
Reliable and Advanced Predictors for Corporate Financial Choices in Pakistan*
}

\author{
Umeair SHAHZAD ${ }^{1}$, Luo FUKAI ${ }^{1}$, Faisal MAHMOOD ${ }^{2}$, Liu JING ${ }^{3}$, Zahoor AHMED ${ }^{4}$ \\ Received: May 08, 2020 Revised: May 17, 2020 Accepted: June 07, 2020
}

\begin{abstract}
Existing studies disagree over the core predictors of firm-level financial choices in developing countries. The general practice only validates the traditional capital structure model, which leads to inconsistency and a lack of novelty. This study removed overfitting issues among existing factors and presented the most reliable and advanced capital structure model in Pakistani firms. The panel data include 368 Pakistani companies from 19 non-financial sectors over the period 2004 to 2017. We apply Akaike and Bayesian Information Criteria to remove overfitting issues among inconsistent proxies in the capital structure model. The fixed effects regression is used for basic results and the Generalized Method of Moments is applied to control the endogeneity. Besides the conventional proxies, we report that credit rating, distance from bankruptcy, managerial concentration, and institutional quality are the most advanced capital structure determinants in Pakistan. These predictors remain significant across firm size and growth levels. Also, the findings confirm that new predictors are reliable to define capital structure dynamics and improve the speed of adjustment in overall and sub-sample analysis. The major findings suggest that managers and policymakers should consider these advanced predictors to design their financial settings in firms.
\end{abstract}

Keywords : Capital Structure, Adjustment Speed, Institutional Quality, Bayesian Information Criteria, Pakistan Stock Exchange

JEL Classification Code: G30, G32, G39.

\section{Introduction}

The seminal work by Frank and Goyal (2009) initiated a debate on the reliability of capital structure determinants in the US economy followed by Chang et al. (2014) in

*We are grateful to the Editor in Chief for his time and many constructive comments that significantly improved the quality of this study. This study was funded by Management College, Ocean University of China.

${ }^{1}$ First Author and Corresponding Author. PhD Scholar, Accounting Department, Management College, Ocean University of China, China [Postal Address: 238 Songling Road, Qing Dao, Shandong, P.R. China 266100] Email: mehrzadah009@yandex.com

${ }^{2}$ School of Economy and Management, Harbin Institute of Technology,

China. Email: faisal_mahmood217@yahoo.com

${ }^{3}$ Henan University of Economics and Law, China.

Email: accaf6uk@126.com

${ }^{4}$ School of Management and Economics, Beijing Institute of Technology, China. Email: zahoorahmed83@yahoo.com

(c) Copyright: The Author(s)

This is an Open Access article distributed under the terms of the Creative Commons Attribution Non-Commercial License (http://Creativecommons.org/licenses/by-nc/4.0/) which permits unrestricted noncommercial use, distribution, and reproduction in any medium, provided the original work is properly cited.
Chinese firms. The current literature emphasizes the role of institutional differences in corporate financial choices in emerging economies (De Jong et al. 2007; Gungoraydinoglu \& Öztekin, 2011). Various scholars report capital structure determinants in developing economies. Most of them confirm the consistency of conventional determinants and overlook the role of institutional and governance differences. The inconsistent capital structure models fail to capture an accurate picture and can negatively affect corporate financial decisions (Frank \& Goyal, 2009). Therefore, it is important to revisit and extend the traditional model of corporate financial choices in developing economies.

There are a few aspects that make Pakistan a unique platform for the capital structure study. The weak governance structure and low investors' protection in Pakistan are not much different from other developing economies, but the ownership structure is highly concentrated. The leading critical players of corporate ownership are local family groups and state (Javid \& Iqbal, 2008). Although the recent financial and governance reforms of 2002 and 2012 improve credit opportunities, still the government's stake in financial institutions is a barrier between private entities and banks (Ahmad et al. 2016). Debt recovery is one of the most 
prominent challenges in the banking sector of Pakistan due to ineffective bankruptcy law. Therefore, the prevalence of short-term debts is significantly high in Pakistan (Jong et al. 2007). The capital structure model there must reflect these challenges. It is noteworthy that the leading studies on the capital structure model do not reflect these issues (Booth et al. 2001; Fan et al. 2012; Fawad Ahmad, 2011; Kabeer \& Rafique, 2018; Khalid, 2010; Shah et al. 2007). Besides, there is a remarkable disagreement in these studies, which calls for more investigations to capture a true picture of firmlevel debt structure in Pakistan.

The main objective of this study is to remove the overfitting issues among inconsistent predictors and advances the capital structure model to effectively reflects governance features and institutional settings of Pakistan. We follow the empirical methodology of Frank and Goyal (2009) to estimate the most reliable and advanced predictors of capital structure in Pakistan. The BIC approach confirms that nine determinants are the most consistent and dependable in Pakistan. We classify these predictors in two main categories, i.e., conventional and advanced predictors. The findings confirm that profitability, industry leverage, size, tangibility, and liquidity are the most consistent and conventional predictors of capital structure in Pakistan. Apart from this, credit rating, distance from bankruptcy, managerial concentration, and state-level institutional quality are the most advanced and consistent predictors. We strengthen these predictors across firm size and growth level to increase the reliability of results. We regress these factors in the presence of inconsistent proxies to confirm their consistency. The final capital structure model remains reliable in all alternative specifications. In the context of capital structure dynamics, we examine the reliability of these predictors to define the speed of adjustment (SOA). These predictors significantly represent the SOA in our sample firms towards the target leverage ratio. Surprisingly, SOA improves in the presence of our advanced predictors. It means credit rating, institutional quality, and distance from bankruptcy positively play a significant role to reduce the cost of debt which leverages the SOA in our sample firms.

Justifying the novelty, we contribute to the existing literature on capital structure study in the following manner. Firstly, we remove overfitting issues among various inconsistent proxies of capital structure determinants applying the Bayesian Information Criteria (BIC) as the most effective econometrics tool. The previous practice is not more than validating traditional proxies and an attempt to advance the literature is very rare. In particular, this attempt contributes to drop inconsistent proxies to suggest a more reliable capital structure model in an emerging economy. Secondly, we complement credit rating, distance from bankruptcy, institutional quality, and managerial concentration as the most advanced predictors of capital structure in Pakistan. These predictors reflect the debt restrictions, bankruptcy, and institutional quality in Pakistan, which were never explored before. Thirdly, we contribute to the current debate on capital structure dynamics in emerging economies. The findings validate a target debt ratio and slow speed of adjustment in Pakistani firms. The firms with good credit rating and high distance from bankruptcy move rapidly towards target debt with high-speed adjustment. Therefore, reliance on traditional proxies is not enough to design a corporate financial setting.

The rest of this study is organized as follows. Section 2 reports the literature review and theoretical predictions; Section 3 discusses material and methodology; Section 4 explains the results and discussion; and Section 5 presents conclusions.

\section{Literature Review}

Three well-known theories support the literature on corporate financial choices. The trade-off theory suggests that capital structure bases on an equilibrium between the cost of debt and potential tax incentives (Myers, 1984). The pecking-order theory predicts that information asymmetries play a critical role to design corporate financial choices (Myers \& Majluf, 1984). The agency theory suggests that firms use debt as a shield to resolve principal-agent agency conflicts (Stulz, 1990). The previous studies report their findings in the context of the above-mentioned theoretical predictions. Shah et al. (2007) report that tangibility, size, and risk have direct effects, and growth, profitability, and tax shield have a negative association with book leverage in Pakistani firms. Khalid (2010) reports that size and risk have a negative role in the capital structure model of Pakistani firms. He extended the capital structure model and report the impact of financial liberalization reforms. He showed that these reforms encouraged equity issuance and play a negative role in firm-level debt financing.

Ahmad (2011) reports a negative association of tangibility and risk on debt financing and extends the model with liquidity as a new factor of capital structure model. Fan et al. (2012) consider 114 non-financial Pakistani companies in 39 cross countries comparison of capital structure. They discuss state-level legal, tax, and corruption, and preference of financial institutions play a substantial role in defining capital structure dynamics and debt maturity ratios. Sheikh and Wang (2011) report that risk, assets structure, profitability has direct, whereas the size has a positive association with debt financing in Pakistani firms. They extend this debate and discuss the role of firm-level governance in the capital structure study of Pakistani firms. They report managerial concentration plays a direct and significant role in designing the corporate financial structure in Pakistani firms (Sheikh \& Wang, 2012). These are the leading studies of capital structure 
studies in Pakistan with a large absence of consensus. Therefore, we decide to revisit the capital structure study and extend this debate introducing institutional quality, credit rating, and distance from bankruptcy as new factors defining capital structure studies in Pakistan.

\subsection{Institutional Quality}

The developing states are very different in their institutional settings from western firms (La Porta et al. 1999). In previous literature, De Jong et al. (2007) and Öztekin (2015) pay specific attention to the role of institutional quality in the study of capital structure. Recently, Matemilola et al. (2019) report that the role of institutional quality in the capital structure study in 37 developing countries. Following their practice, we use six basic state-level governance indicators, i.e., the rule of law, regulatory quality, government effectiveness, political stability, voice and accountability, and control of corruption defined by the World Bank as world development indicators. We expect the institutional quality is an external force that assures the debt environment and directly impacts corporate financial choices.

\subsection{Credit Rating}

The role of credit supply plays a significant role in restricted credit markets (Faulkender \& Petersen, 2006). Financial institutions in emerging economies prefer firms with high credit ratings (Han et al. 2016). Later on, Frank and Goyal (2009) complement this factor in their long list of capital structure determinants in US firms. They assume a direct relationship between credit rating and leverage. According to Faulkender and Petersen (2006), credit rating is a significant predictor of capital structure in a restricted credit market. The debt is highly restricted in Pakistan due to tough debt requirements (Ahsan et al. 2016; Booth et al., 2001; De Jong et al., 2007). The financial institutions pay strict attention to the credit rating status due to bankruptcy and debt recovery issues in Pakistan. To the best of our knowledge and the cited literature, this is the most overlook factor in the capital structure study of developing economies. We expect the firms with high credit ratings are in a better position to avoid debt opportunities in Pakistan.

\subsection{Distance from Bankruptcy}

The static trade-off theory predicts that firms keep target leverage, and dynamic theory suggests a leverage adjustment towards the target ratio. The main reason for keeping target leverage and adjustment towards the target ratio is the equilibrium between bankruptcy cost and tax incentives (Jong et al. 2007). The Trade-off theory hypothesizes that low profitability enhanced the risk of bankruptcy (Fama \& French, 2002), which bound firms to keep low leverage. The distance from bankruptcy, especially in emerging economies, is a major concern. Therefore, the distance from bankruptcy can be a significant predictor of capital structure. The statistical outcomes of Kayo and Kimura (2011) significantly confirm the reliability of this predictor. The measurement of the distance from bankruptcy is another challenge. The Altman Z score model modified by Macki-Mason (1990) is assumed as an effective measuring tool for the distance from bankruptcy (Byoun, 2008). Equation 1 reports the detailed formula of the Altman $\mathrm{Z}$ score as a proxy for distance from bankruptcy.

$$
\begin{aligned}
& \text { Equation } 1 \\
& \begin{aligned}
Z & =3.3\left(\frac{\text { EBIT }}{\text { T.Assets }}\right)+1.0\left(\frac{\text { Total Sales }}{T . \text { Assets }}\right) \\
& +1.4\left(\frac{\text { Retained Earning }}{T . \text { Assets }}\right) \\
& +1.4\left(\frac{\text { Working Capital }}{\text { T.Assets }}\right)
\end{aligned}
\end{aligned}
$$

\section{Material and Methods}

\subsection{Variable Measurement}

There are two main proxies used to measure capital structure, i.e., book and market leverage. Book leverage is the most favorable and adoptable proxy in developing economies. Therefore, we adopt this proxy, which represents the ratio of total debt to total assets. Here, total debts include short and long term interest-bearing contractual liabilities. We adopt two proxies to measure firm-level size, the natural log value of total sales, and firm age. The firm age is the difference between a firm listing year and the current year. We apply return on assets to measure corporate profitability, which is equal to operating income divided by total assets. Three common proxies are used to measure corporate growth in this study. Firstly, assets growth, which is the ratio of change in assets to opening assets value. Secondly, we adopt a market book ratio, which is the ratio of the market value of a firm to total assets. The market value of a firm is equal to the total debt plus market value of equity. The market value of equity is measured by multiplying closing share price with ordinary shares outstanding. Thirdly, the capital expenditure ratio, which is equal to the change in fixed assets divided by total assets.

We adopt two common proxies for tangibility. Firstly, the fixed assets ratio, which is equal to fixed assets divided by total assets. Secondly, we add an Industry dummy 
variable equal to 1 if a firm is operating in information and communication, coke and refined petroleum products, mineral products, electric machinery, and apparatus industry; 0 otherwise.

There are two effective proxies to measure corporate tax. Firstly, a non-debt tax shield is equal to annual depreciation divided by total assets. Secondly, the effective tax rate is the ratio of income tax expenses to operating profit before tax. We use corporate debt rating status as a proxy for credit supply, which is equal to 1 if a firm has credit rating status and 0 otherwise. The industry-level median value of book leverage is used as industry condition proxy.

We measure liquidity as a current asset to current liabilities. Now, we discuss the proxies applied to examine country and institutional level impact in the capital structure model. Firstly, we apply managerial concentration to examine the impact of the CEO on corporate debt decisions (Vijayakumaran \& Vijayakumaran, 2019). Managerial concentration is a dummy variable that is equal to 1 if the CEO holds $10 \%$ equity shares; 0 otherwise. The state-level governance index is used as the proxy for institutional quality. According to the World Bank development indicators rule of law, the regularity of quality, governance effectiveness, political stability, voice and accountability, and control of corruption are used to examine state-level institutional quality index. We use the index value of each variable and apply CGI equal to the sum of above mentioned six indicators as the proxy for state-level governance quality. We add inflation rate, GDP growth, and annual interest rate to examine the economic impact on firm-level capital structure.

\subsection{Econometrics Specifications}

We follow the practice of Frank and Goyal (2009) and Chang et al. (2014) to remove the overfitting issues among capital structure factors in Pakistani firms.

Equation 2 reports the baseline regression model.

Equation 2

$$
\operatorname{Lev}_{i, t}=\alpha+\sum_{j=n}^{n} \beta_{J} F_{i, t-1}+\eta_{i}+\ddot{\mathrm{e}}_{t}+\varepsilon_{i t}
$$

In Equation 2, Levi,t defines the leverage of firm i on $t$ period, whereas $\sum_{j=n}^{n} \hat{a}_{j} F_{i, t-1}$ explains the long list of predictors of firm $i$ with one year lagged period. The vector is, represents constant value, is represents industry effect, which changes over time but remains constant within the industry. Where, is time dummy which changes over time and is an error term of the firm in t period.
We have a long list of 18 predictors, which are subject to drop overfitted and inconsistent predictors. According to Hastie et al. (2001), the Akaike Information Criterion (AIC) and Bayesian Information Criterion (BIC) are the most suitable model selection methodologies. The BIC is the best approach to control overfitting and high probability issues of each fitted predictor in the regression model.

Equation 3

$$
\text { BIC }=-2 \times \log \text { probability }+P \times \log (N)
$$

In Equation 3, $\mathrm{P}$ is a parameter frequency, and $\mathrm{N}$ is the observation frequency in a fitted model. Following the rule of thumb, smaller BIC and AIC are most favorable. The value of BIC indirectly relates to log probability. It refers directly to the frequency of parameters and observations. The methodology of Akaike Information Criterion (AIC) is almost likewise but with the number 2 replacing $\log (\mathrm{N})$ in the specification. Firstly, we complement a long list of predictors in Equation 2 and noting down beta and $t$ statistics of each determinant. Secondly, we drop one factor with the lowest $t$ value and repeat the regression with residuals. Thirdly, we repeat these two steps until a single residual with the highest $t$ value. We record AIC and BIC statistics for each model. We assume the model with the smallest amount of AIC and BIC as an optimal model. This process drops only those factors which do not meet the criteria of AIC and BIC.

\subsection{Research Methodology}

The primary objective of this study is to remove overfitting issues among inconsistent capital structure determinants. Therefore, BIC and AIC criteria are used to address this matter. The fixed effect estimation is applied for basic analysis. The fixed effect method is the most frequently used estimator in the previous literature. The main issues with the fixed effect estimations are limitations to address the potential endogeneity (Hill et al. 2019). The second statistical problem of this study is controlling the endogeneity. We apply an instrumental variable generalized method of moments (IV-GMM) in our panel data. This tool uses 2-steps efficient generalized method of moments and reports effective results controlling endogeneity and heterogeneity. This is one of the most reliable tools that execute accurate coefficient values as well as the consistent estimation of standard errors. The instrumental variables (IV-GMM) approach is one of the most effective methods to control heteroskedasticity, the validity of instruments, over and under-identification restrictions. The statistics of the Kelibergen-Paap RK LM test, Cragg-Donald Wald test, 
Hansen $\mathrm{J}$ test confirm under, weak, and over-identification of instruments. We used STATA 15 software for analysis.

\subsection{Data Source}

The study is based in Pakistan. We obtained 14 years' worth of secondary data (2004 - 2017). The source of the data was the Statistics \& DWH Department and State Bank of Pakistan. The credit rating information of our sample firms is obtained from the Pakistan Credit Rating Agency (PACRA) and VIS Credit Rating Company Limited. These two institutions are independent financial research organizations operating as Full-Service credit rating agencies in Pakistan under the approval of the Security Exchange Commission of Pakistan (SECP) and State Bank of Pakistan (SBP). The data on institutional quality collected from the world governance indicator sourced by the website of the World Bank. We drop all observations with negative shareholder equity and missing values. The extreme top and bottom values are removed from the data to mitigate the outliner effect. The final sample of our study consists of 368 nonfinancial firms, representing 4611 years of observation that covers the period $2004-2017$.

\section{Results}

\subsection{Descriptive Statistics}

Table 1 reports the descriptive statistics of variables used across this study. The mean value of book leverage is 0.297 , which is consistent with that reported in developing countries (Booth et al. 2001; Jong et al. 2007). The descriptive of growth proxies, i.e., market-to-book ratio (MBR) and sales growth (S_grow) as 0.974 and 0.167 , are quite lower than the Chinese firms, but consistent with the previous literature in developing economies. It means that the Pakistani firms do not enjoy lucrative growth opportunities due to a lack of sufficient debt supply from financial institutions. The mean value of ETR is only $18 \%$ quite lower than other developing economies in the world. It implies that listed firms in Pakistan bear a lighter amount of income tax burden. The mean value of managerial holding measured as is 0.699 represents the largest managerial concentration in Pakistan (Sheikh \& Wang, 2012).

\subsection{Correlation Matrix and Variance Inflation Matrix}

There are two primary measures to examine multicollinearity errors in data, i.e. Pearson correlation analysis and variance inflation score. We do not report the correlation index score for the sake of brevity and article space limit. The correlation score among the independent variable is not so strong to create multicollinearity issues. The variance inflation factor score lower than 5.0 does not keep multicollinearity issues (Studenmund \& Cassidy, 1992). We analyzed the VIF score in our panel data. The VIF scores of all variables remain lower than 5.0. Figure 1 shows the results.

\subsection{Reliable Predictors and Overfitting Issues}

We follow the practice of Frank and Goyal (2009) as a rule of thumb in this study. The factors assume as core determinant if (1) it include in a model of minimum AIC and BIC of overall samples; (2) remains consistent with minimum AIC and BIC at least in 50\% of annual subsample; (3) remains consistent with minimum AIC and BIC at least in $50 \%$ of random subsamples.

Table 2 reports our statistical outcomes. The regression model at the bottom of Table 2 contains 18 different proxies of all possible determinants of capital structure examined in the previous literature. The explanatory power of this model is $35.51 \%$ with $(-5869.78)$ as BIC statistics. In this overall specification, we find the industrial uniqueness (UNIQ) as the worst-performing factor with the lowest $t$ value $(-0.54)$. We drop this factor and repeat the regression process on residuals.

We observe a fall in BIC value from -5869.78 to -5877.78 with residuals. In this specification, we find age as the worst-performing factor with the lowest $t$-value $(-0.32)$. We continue this process and find continuous fall in AIC and BIC statistics up to model 11. The model 11 has the most suitable specification with AIC (-6062.65) and BIC with (-5925.96). This model contains the variables as the optimal specifications defining leverage. The reliability and consistency of these variables is another job. We continue with this process to robust our models across 10 equal-sized random subsamples of the population. This study finds nine variables that are assuring the benchmark of core factors, i.e. (1) liquidity (LIQ); (2) distance from bankruptcy (DFBC); (3) debt supply (Debt_Supply); (4) industrial leverage (INDLEV); (5) managerial concentration (MangCon); (6) size (InSales); (7) institutional quality (CGI); (8) profitability (ROA); and (9) tangibility (TANG). Although model 11 carries sales growth and effective tax rate, unluckily, they fail to meet robustness criteria. Therefore, we drop both proxies to be assumed as core determinants. Five of the nine core determinants (industry leverage, size, ownership structure, tangibility, and profitability) are among the core determinants by Chang et al. (2014) in the Chinese market. Moreover, to the best of our knowledge, this study is first to examine the explanatory power of credit rating, distance from bankruptcy, and institutional quality in Pakistan. 
Table 1: Descriptive Analysis

\begin{tabular}{|c|c|c|c|c|c|}
\hline Variables & $\mathbf{N}$ & Mean & SD & MIN & MAX \\
\hline Leverage (LEV) & 4,611 & 0.2967 & 0.2121 & 0 & 0.7771 \\
\hline \multicolumn{6}{|l|}{ Firm-Specific } \\
\hline In(Sales) & 4,611 & 14.7532 & 1.7744 & 9.4251 & 18.9786 \\
\hline Age & 4,611 & 41.4229 & 18.1986 & 10 & 104 \\
\hline ROA & 4,611 & -0.4426 & 0.4205 & -1 & 0.2758 \\
\hline S_Growth & 4,611 & 0.167 & 0.5644 & -0.981 & 3.8829 \\
\hline MBR & 4,611 & 0.9748 & 1.2467 & 0.0821 & 9.1182 \\
\hline CAPEX & 4,611 & 0.0249 & 0.1352 & -0.731 & 0.5002 \\
\hline TANG & 4,611 & 0.4663 & 0.2311 & 0.0046 & 0.9538 \\
\hline NDTS & 4,611 & 0.0328 & 0.0203 & 0 & 0.1222 \\
\hline ETR & 4,611 & 0.1889 & 0.2344 & 0 & 1 \\
\hline LIQ & 4,611 & 1.551 & 1.6584 & 0.0806 & 11.8115 \\
\hline DFBC & 4,611 & 0.123 & 1.7083 & -3.8857 & 4.6895 \\
\hline Debt_Supply & 4,611 & 0.2999 & 0.4582 & 0 & 1 \\
\hline \multicolumn{6}{|l|}{ Industry Specific } \\
\hline UNIQ & 4,611 & 0.1858 & 0.389 & 0 & 1 \\
\hline Ind_LEV & 4,611 & 0.2473 & 0.1208 & 0.0068 & 0.5201 \\
\hline \multicolumn{6}{|l|}{ Economic Specific } \\
\hline Int_Rate & 4,611 & 1.7682 & 4.5022 & -6.774 & 8.3214 \\
\hline INF & 4,611 & 9.159 & 4.5439 & 2.5293 & 20.2861 \\
\hline GDP_Growth & 4,611 & 4.4921 & 1.834 & 1.6061 & 7.6673 \\
\hline \multicolumn{6}{|l|}{ Institutional Specific } \\
\hline CGI & 4,611 & 20.376 & 1.814 & 17.783 & 24.605 \\
\hline Managerial Concentration & 4,611 & 0.6974 & 0.4594 & 0 & 1 \\
\hline
\end{tabular}

Note: All variables are winsorized at 1 to $99 \%$ to mitigate the outliner effect.

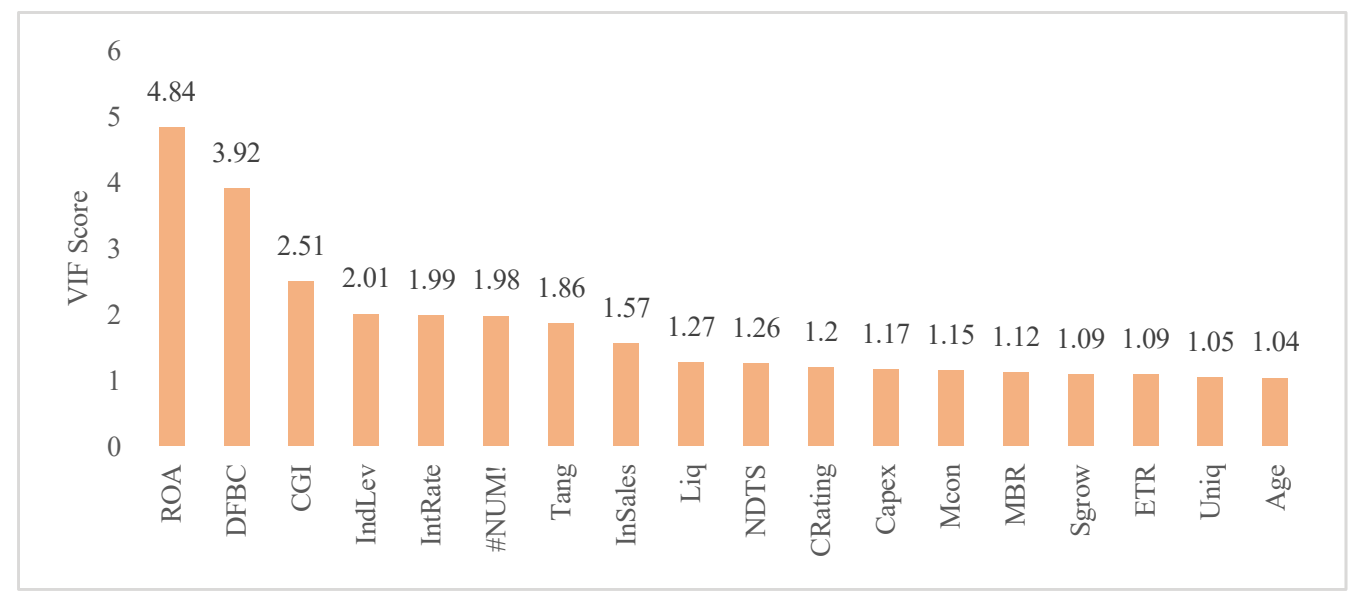

Figure 1: VIF score of all variables 
Table 2: Selection of core predictors applying AIC and BIC estimation

\begin{tabular}{|c|c|c|c|c|c|c|c|c|}
\hline \multirow{3}{*}{ Variables } & \multirow{2}{*}{$\beta$} & \multirow{2}{*}{ t Stat } & \multirow{2}{*}{$\mathbf{R}^{2}$} & \multirow{2}{*}{ Ind. $\mathbf{R}^{2}$} & \multirow{2}{*}{ AIC } & \multirow{2}{*}{ BIC } & \multicolumn{2}{|c|}{ Robustness } \\
\hline & & & & & & & Positive & Negative \\
\hline & 01 & 02 & 03 & 04 & 06 & 07 & 08 & 09 \\
\hline LIQ & -0.0171 & -9.53 & 0.2497 & 0.2192 & -6043.85 & -5923.60 & 0 & 100 \\
\hline DFBC & -0.0347 & -12.76 & 0.2314 & 0.2158 & -5945.69 & -5831.77 & 0 & 100 \\
\hline TANG & 0.0905 & 5.93 & 0.1933 & 0.1864 & -5749.20 & -5647.94 & 90 & 10 \\
\hline Debt_Supply & 0.0497 & 4.5 & 0.1976 & 0.1843 & -5769.76 & -5662.17 & 100 & 0 \\
\hline INDLEV & 0.2452 & 5.51 & 0.1856 & 0.1856 & -5712.18 & -5617.25 & 100 & 0 \\
\hline ManCon & 0.0380 & 3.1 & 0.2517 & 0.1813 & -6052.54 & -5910.76 & 100 & 0 \\
\hline In(Sales) & 0.0055 & 2.21 & 0.2527 & 0.1799 & -6055.98 & -5923.07 & 100 & 0 \\
\hline CGI & 0.0130 & 2.13 & 0.2527 & 0.1790 & -6055.97 & -5923.1 & 50 & 20 \\
\hline ROA & -0.0381 & -1.99 & 0.2535 & 0.1832 & -6058.39 & -5919.16 & 10 & 90 \\
\hline Sale_Growth & -0.0078 & -2.09 & 0.2543 & 0.1791 & -6061.25 & -5915.69 & 0 & 40 \\
\hline ETR & 0.0173 & 1.74 & 0.3290 & 0.1794 & -6062.65 & -5925.96 & 10 & 30 \\
\hline INF & 0.0086 & 1.10 & 0.3249 & 0.1790 & -6062.65 & -5910.75 & 0 & 0 \\
\hline IntRate & 0.0023 & 0.76 & 0.3349 & 0.1790 & -6062.65 & -5910.75 & 0 & 0 \\
\hline MBR & 0.0003 & 0.15 & 0.3349 & 0.1793 & -6060.67 & -5902.45 & 10 & 0 \\
\hline CAPEX & -0.0058 & -0.34 & 0.3450 & 0.1879 & -6058.79 & -5894.25 & 30 & 20 \\
\hline NDTS & -0.0375 & -0.25 & 0.3550 & 0.1790 & -6056.87 & -5885.99 & 30 & 40 \\
\hline AGE & -0.0001 & -0.32 & 0.3450 & 0.1790 & -6054.98 & -5877.78 & 0 & 0 \\
\hline UNIQ & -0.0693 & -0.54 & 0.3551 & 0.1790 & -6053.31 & -5869.78 & 0 & 0 \\
\hline
\end{tabular}

Note: The table reports the statistical outcomes of basic predictors using book value leverage definition. The fixed effect estimation is used for estimation and we cluster to control the intraclass correlation impact by adjusting standard error at the firm and year level. All variables are winsorized at $1 \%$ to $99 \%$ and ${ }^{* * *} p<0.01,{ }^{* *} p<0.05,{ }^{*} p<0.1$ indicates the standard errors value.

\subsection{Firm-specific Features and Capital Structure Determinants}

We examine the reliability of core determinants across size and growth. We expect the reliability of our core predictors across firms' different specifications. We report our statistical outcomes in Table 3. The score of the LM test is highly significant in all specifications that confirm the absence of under-identification error. Moreover, the Wald F statistics are higher than the critical value of the Stock-Yogo weak ID test that confirms the strength of instruments. Finally, the P-Value of the Hansen test is higher than 0.10 , which confirms the absence of over-identification error. In the context of these statistics, our model perfectly controls multicollinearity, endogeneity, and over or underidentification errors.

As reported in Table 3, all of our predictors are highly significant in various specifications of firms as per size and growth. We find insignificance results of industry leverage in high growth and small size firms and ownership structure in low growth firms. The most common research methodology in previous literature is the fixed effect method. It is a consensus that the fixed-effect method is useful in static panel data. Therefore we robust our analysis applying fixed effect estimation and results remain significant. We do not report the results for the sake of brevity but can be provided on demand.

\subsection{Reinforcement of Minor Predictors in Full Regression}

We cannot ignore the interest of minor predictors. There are several reasons to compliment them in the most consistent regression model of this study. Minor factors may impact on the significance of our core predictors. Sometimes, minor predictors are essential for a specific policy matter, and then it is essential to add them to the regression model of core predictors (Frank \& Goyal, 2009). Therefore, we add minor factors in three different models and examine their impact on our core predictors. We find minor predictors do not change the explanatory power of our core predictors. In model 1, we control industry leverage, institutional quality, 
Table 3: Reliability of Core predictors across firm size and growth level

\begin{tabular}{|c|c|c|c|c|c|}
\hline \multirow{2}{*}{ Variables } & \multirow{2}{*}{ Overall } & \multicolumn{2}{|c|}{ Growth } & \multicolumn{2}{|c|}{ Size } \\
\hline & & Low & High & Large & Small \\
\hline \multirow[t]{2}{*}{ DFBC } & $-0.042^{* * *}$ & $-0.041^{* * *}$ & $-0.050^{* * *}$ & $-0.059^{\star * \star}$ & $-0.026^{* * *}$ \\
\hline & $(0.004)$ & $(0.006)$ & $(0.007)$ & $(0.006)$ & $(0.006)$ \\
\hline \multirow[t]{2}{*}{ ROA } & $-0.241^{* * *}$ & $-0.203^{* * *}$ & $-0.273^{* * *}$ & $-0.129^{* * *}$ & $-0.295^{* * *}$ \\
\hline & $(0.037)$ & $(0.048)$ & $(0.062)$ & $(0.050)$ & $(0.053)$ \\
\hline \multirow[t]{2}{*}{ IndLev } & $0.147^{* *}$ & $0.190^{\star *}$ & 0.077 & 0.127 & $0.165^{*}$ \\
\hline & $(0.062)$ & $(0.085)$ & $(0.091)$ & $(0.080)$ & $(0.098)$ \\
\hline \multirow[t]{2}{*}{ Size } & $0.012^{* * *}$ & $0.014^{* * *}$ & $0.009^{* *}$ & $-0.007^{*}$ & $0.026^{* * *}$ \\
\hline & $(0.002)$ & $(0.003)$ & $(0.004)$ & $(0.004)$ & $(0.004)$ \\
\hline \multirow[t]{2}{*}{ Tang } & $0.149^{\star * \star}$ & $0.179^{\star \star \star}$ & $0.196^{\star \star *}$ & $0.060^{* *}$ & $0.196^{\star * \star}$ \\
\hline & $(0.017)$ & $(0.021)$ & $(0.028)$ & $(0.024)$ & $(0.025)$ \\
\hline \multirow[t]{2}{*}{ Liq } & $-0.026^{\star * *}$ & $-0.026^{* * *}$ & $-0.022^{* * *}$ & $-0.033^{* * *}$ & $-0.022^{* * *}$ \\
\hline & $(0.002)$ & $(0.002)$ & $(0.005)$ & $(0.005)$ & $(0.002)$ \\
\hline \multirow[t]{2}{*}{ Crating } & $0.049^{* * *}$ & $0.153^{* * *}$ & $0.058^{* * *}$ & $0.046^{* * *}$ & $0.036^{* * *}$ \\
\hline & $(0.006)$ & $(0.021)$ & $(0.009)$ & $(0.007)$ & $(0.012)$ \\
\hline \multirow[t]{2}{*}{ MangCon } & $0.022^{* * *}$ & $0.035^{\star * *}$ & $0.142^{* * *}$ & $0.033^{* * *}$ & -0.004 \\
\hline & $(0.007)$ & $(0.009)$ & $(0.028)$ & $(0.008)$ & $(0.010)$ \\
\hline \multirow[t]{2}{*}{ CGI } & $0.187^{* * *}$ & 0.009 & $0.038^{* * *}$ & $0.158^{* * *}$ & $0.211^{* * *}$ \\
\hline & $(0.017)$ & $(0.009)$ & $(0.010)$ & $(0.022)$ & $(0.024)$ \\
\hline \multirow[t]{2}{*}{ Constant } & $-0.229^{* * *}$ & $-0.238^{* * *}$ & $-0.195^{\star *}$ & $0.189^{* *}$ & $-0.456^{* * *}$ \\
\hline & $(0.049)$ & $(0.065)$ & $(0.080)$ & -0.082 & $(0.074)$ \\
\hline $\mathrm{N}$ & 3,688 & 2,094 & 1,594 & 1,997 & 1,691 \\
\hline R-squared & 0.340 & 0.333 & 0.379 & 0.406 & 0.357 \\
\hline $\begin{array}{l}\text { Kleibergen-Paap rk } \\
\text { LM statistic }\end{array}$ & 519.91 & 256.01 & 312.07 & 397.02 & 198.91 \\
\hline Wald F statistic & 349.37 & 177.92 & 198.53 & 413.31 & 107.31 \\
\hline Hansen J Statistics & 0.589 & 0.176 & 0.441 & 0.187 & 0.424 \\
\hline
\end{tabular}

Note: The table reports the reliability of the most consistent determinants across firms' growth and size levels. The firm's growth divide as per asset growth. All of the firms divided into four equal quartiles. The firms in the lowest quartile are low growth firms, and the highest quartiles are high growth firms. The same criteria adopted to classify firms as per their investment value in assets. ${ }^{* *} p<0.01,{ }^{* *} p<0.05,{ }^{*}$ $p<0.1$ indicates the standard errors value.

and managerial concentration. In model 2, we add industry leverage but control the institutional quality and managerial concentration. In model 3, we regress all core predictors along with minor predictors.

We do not report the results of core predictors for the sake of brevity. We find our core predictors remain highly significant in all specifications. The minor predictors do not change on the explanatory power and significance level of our core predictors. The interesting fact of these outcomes is the significance level of various minor predictors. For instance, the coefficient values of two growth proxies, i.e., sales growth, CAPEX remain significant in all specifications. The coefficient values of NDTS, ETR, and Inflation remain significant in all specifications. It suggests that various minor predictors can add to the core regression model of this study, and they remain statistically significant. This is the reason the previous literature reports these predictors as highly significant, but their effects are weak than our core predictors. The results can be provided on request. 


\subsection{Core Predictors and Speed of Adjustment}

Capital structure dynamic is an important topic in modern literature. It is a general practice to examine capital structure dynamics (Nguyen et al. 2019). Therefore, we examine the reliability of the target ratio and speed of adjustment in the context of our core predictors. We complement lag leverage in our baseline regression equation of core predictors. Equation 4 reports the regression model for capital structure dynamics.
Equation 4

$$
\begin{aligned}
& \operatorname{Lev}_{i, t}=\alpha+1-\delta\left(\operatorname{Lev}_{i, t-1}\right)+ \\
& \sum_{j=6}^{n} \beta_{J} C P_{i, t-1}+\ddot{\mathrm{e}}_{t}+\varepsilon_{i t} \\
& \operatorname{Lev}_{i, t}=\alpha+1-\delta\left(\operatorname{Lev}_{i, t-1}\right)+ \\
& \sum_{j=09}^{n} \beta_{J} C P_{i, t-1}+\ddot{\mathrm{e}}_{t}+\varepsilon_{i t}
\end{aligned}
$$

\begin{tabular}{|c|c|c|c|c|}
\hline \multicolumn{5}{|c|}{ Panel A: Capital structure dynamics in overall samples } \\
\hline Variables & Model 04a & Model 04b & & \\
\hline \multirow[t]{2}{*}{ Lag LEV } & $0.515^{\star * *}$ & $0.473^{* * *}$ & & \\
\hline & -0.013 & -0.014 & & \\
\hline \multirow[t]{2}{*}{ Constant } & 0.006 & $-0.152^{* * *}$ & & \\
\hline & -0.029 & -0.038 & & \\
\hline Control / Year Effect & Yes & Yes & & \\
\hline Observations & 4,142 & 3,829 & & \\
\hline R-squared & 0.483 & 0.498 & & \\
\hline \multicolumn{5}{|c|}{ Panel B: Capital structure dynamics across firm size } \\
\hline \multirow{2}{*}{ Variables } & \multicolumn{2}{|c|}{ Small Size } & \multicolumn{2}{|c|}{$\begin{array}{r}\text { Large Size } \\
\end{array}$} \\
\hline & Model 04a & Model 04b & Model 04a & Model 04b \\
\hline \multirow[t]{2}{*}{ Lag LEV } & $0.429^{\star * *}$ & $0.397^{\star * *}$ & $0.492^{* * *}$ & $0.436^{\star \star *}$ \\
\hline & $(0.021)$ & $(0.021)$ & $(0.018)$ & $(0.019)$ \\
\hline \multirow[t]{2}{*}{ Constant } & $-0.082^{*}$ & $-0.214^{* * *}$ & $0.478^{* * *}$ & $0.170^{* *}$ \\
\hline & $(0.044)$ & $(0.059)$ & $(0.059)$ & $(0.072)$ \\
\hline Control / Year Effect & Yes & Yes & Yes & Yes \\
\hline Observations & 1,981 & 1,873 & 2,161 & 1,956 \\
\hline R-squared & 0.455 & 0.469 & 0.480 & 0.504 \\
\hline \multicolumn{5}{|c|}{ Panel C: Capital structure dynamics across firm size } \\
\hline \multirow{2}{*}{ Variables } & \multicolumn{2}{|c|}{ High Growth } & \multicolumn{2}{|c|}{ Low Growth } \\
\hline & Model 04a & Model 04b & Model 04a & Model 04b \\
\hline \multirow[t]{2}{*}{ Lag LEV } & $0.572^{* * *}$ & $0.535^{* * *}$ & $0.432^{* * *}$ & $0.393^{* * *}$ \\
\hline & $(0.018)$ & $(0.019)$ & $(0.022)$ & $(0.022)$ \\
\hline \multirow[t]{2}{*}{ Constant } & -0.043 & $-0.143^{* * *}$ & $0.163^{* * *}$ & -0.103 \\
\hline & $(0.036)$ & $(0.049)$ & $(0.055)$ & $(0.073)$ \\
\hline Time / Control Effect & Yes & Yes & Yes & Yes \\
\hline Observations & 2,306 & 2,140 & 1,836 & 1,689 \\
\hline R-squared & 0.502 & 0.502 & 0.480 & 0.520 \\
\hline
\end{tabular}

Table 4: Capital structure dynamics in the presence of core predictors

Note: The table reports the statistical outcomes of our core predictors and capital structure dynamics. ${ }^{* * *} p<0.01,{ }^{* *} p<0.05,{ }^{*} p<0.1$ reports Standard errors in parentheses. 
This regression model is a frequently-used model for the reliability of the target leverage ratio and speed of adjustment. The factor represents the target ratio and represents the speed of adjustment. Where ) is one minus coefficient value of lag leverage. The coefficient value of lag leverage represents the cost of the target ratio. The lowest coefficient value means the lowest cost and high speed of adjustment. The term represents the set of our core predictors. The model $4 \mathrm{a}$ includes return-on-assets, liquidity, tangibility, industry leverage, and size as core predictors. Whilst, model $4 \mathrm{~b}$ includes all core predictors and distance from bankruptcy, state-level institutional quality, managerial concentration, and credit rating. This model frequently used in previous literature to examine the capital structure dynamics (Fama \& French, 2002). We report our results in Table 4.

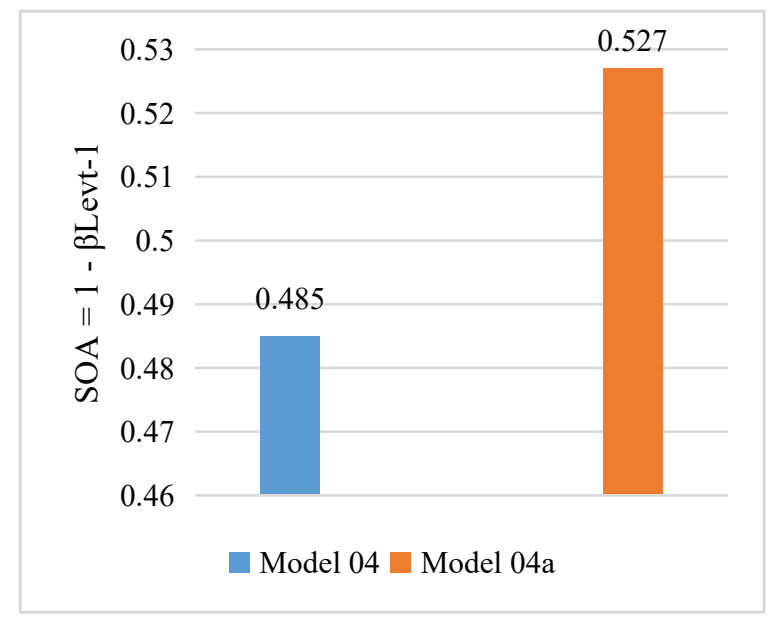

(a) Capital structure dynamics in the overall sample
The statistical outcomes of Table 4 confirm the significance of the target leverage ratio in Pakistani firms. In model 4, the old core predictors are statistically significant in defining the speed of adjustment. The speed of adjustment is (1-0.515) $48.50 \%$ in the presence of old core predictors. The most advanced predictors improve the speed of adjustment. In model $4 \mathrm{~b}$, the speed of adjustment improves from $48.50 \%$ to $52.70 \%$. The credit rating, managerial concentration, distance from bankruptcy, and institutional quality have a direct impact on the speed of adjustment. In recent studies, Ahsan et al. (2016) confirm the target-leverage ratio in Pakistani firms, and Matemilola et al. (2019) confirm the positive role of institutional quality on the speed of adjustment in developing countries. We analyze the speed of adjustment towards the target-debt ratio across firm size and growth levels. Panel B and C carries the detail. The results

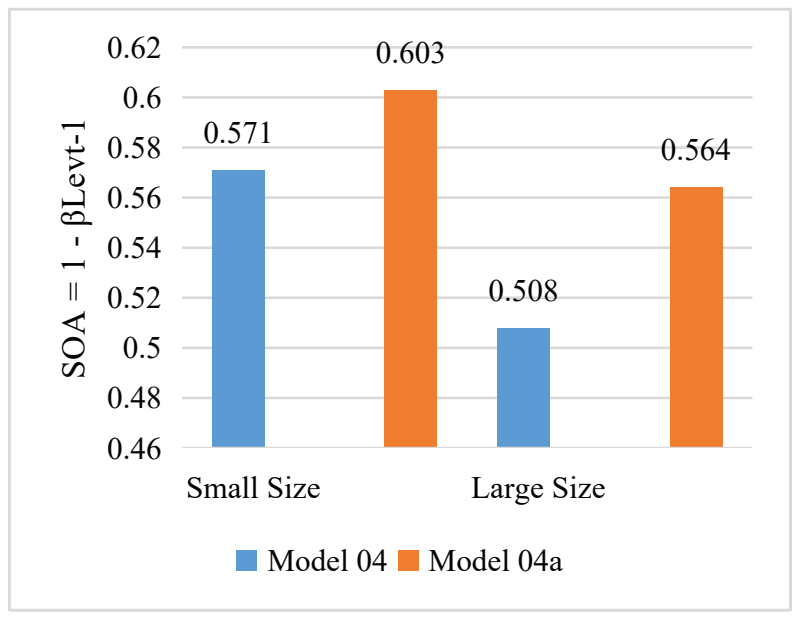

(b) Capital structure dynamics across firm size

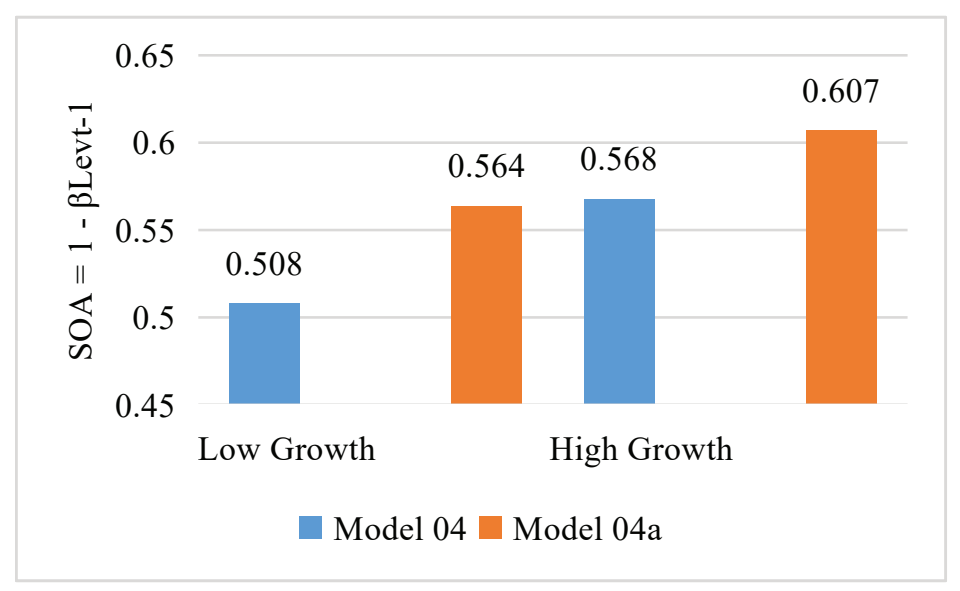

(c) Capital structure dynamics across firm growth level

Figure 2: overall and sub-sample analysis for the capital structure dynamics. 
remain consistent and validate improvement in the speed of adjustment in the presence of new predictors. We plot the exact value of the speed of adjustment $1-\beta$ in Figure 2 for detailed insights.

Figure 2a reports the capital structure dynamics in overall samples, where the speed of adjustment improves from $48.50 \%$ to $52.70 \%$. We apply Equation 4 across firm size and growth level, and report the results in Figure $2 b$ and Figure $2 \mathrm{c}$ respectively. The speed of adjustment improves in all specifications of subsample analysis. It validates that credit rating, distance from bankruptcy, managerial concentration, and institutional quality are reliable predictors to define capital structure dynamics in our sample firms.

\section{Conclusion}

This study presents the most reliable and advanced capital structure model in Pakistani firms. We remove overfitting issues among 18 different proxies reported in the previous literature. Besides, we examine advance predictors, which reflect governance diversity and institutional settings in Pakistan. The BIC approach confirms that nine determinants are the most reliable and consistent in Pakistan. We classify these predictors in two main categories, i.e., conventional and advanced predictors. In the context of conventional predictors, this study reports profitability, industry leverage, size, tangibility, and liquidity are the most consistent and traditional predictors of capital structure in Pakistan. Besides, credit rating, distance from bankruptcy, managerial concentration, and institutional quality are the most advanced and consistent predictors. We test these predictors across firm size and growth level to enlarge the reliability of results.

Also, we regress these predictors in the presence of inconsistent proxies to confirm their consistency. These predictors remain reliable in all alternative specifications. In the context of capital structure dynamics, we examine the reliability of these predictors to define the speed of adjustment. These predictors significantly define the speed of adjustment in our sample firms towards the target leverage ratio. Surprisingly, the speed of adjustment improves in the presence of our advanced predictors. It means credit rating, institutional quality, managerial concentration, and distance from bankruptcy positively impact on the speed of adjustment in our sample firms.

This study provides novel findings on the capital structure determinants in an emerging economy. Our advanced predictors provide new insight into corporate financial choices in emerging economies. Managers and policymakers should pay attention to improve their credit rating, solvency, and state-level institutional quality. We hope that this work will be useful to conduct further studies in emerging economies. We used the state-level governance index as a proxy for institutional quality, which covers the external governance impact. This study has a limitation: it could not extend the analysis in the internal governance system due to data restrictions. Future studies are recommended to apply internal governance quality. The study of inside governance quality can bring better results to reflect the true picture of the capital structure model in Pakistan.

\section{References}

Ahmad, F. (2011). Extension of determinants of capital structure: Evidence from Pakistani non- financial firms. African Journal of Business Management, 5(28). https://doi.org/10.5897/ajbm11.218

Ahmad, M. I., Guohui, W., Hassan, M., Naseem, M. A., \& Rehman, R. U. (2016). NPL and Corporate Governance: A Case of Banking Sector of Pakistan. Accounting and Finance Research, 5(2). https://doi.org/10.5430/afr.v5n2p32

Ahmed Sheikh, N., \& Wang, Z. (2011). Determinants of capital structure: An empirical study of firms in manufacturing industry of Pakistan. Managerial Finance, 37(2), 117-133. https://doi. org/10.1108/03074351111103668

Ahsan, T., Man, W., \& Qureshi, M. A. (2016). Mean reverting financial leverage: theory and evidence from Pakistan. Applied Economics, 48(5), 379-388. https://doi.org/10.1080/00036846. 2015.1080802

Baum, C. F., Schaffer, M. E., \& Stillman, S. (2003). Instrumental Variables and GMM: Estimation and Testing. The Stata Journal: Promoting Communications on Statistics and Stata, 3(1), 1-31. https://doi.org/10.1177/1536867x0300300101

Booth, L., Aivazian, V., Demirguc-Kunt, A., \& Maksimovic, V. (2001). Capital structures in developing countries. Journal of Finance, 56(1), 87-130. https://doi.org/10.1111/00221082.00320

Byoun, S. (2008). How and when do firms adjust their capital structures toward targets? Journal of Finance, 63(6), 30693096. https://doi.org/10.1111/j.1540-6261.2008.01421.x

Chang, C., Chen, X., \& Liao, G. (2014). What are the reliably important determinants of capital structure in china? Pacific Basin Finance Journal, 30, 87-113. https://doi.org/10.1016/j. pacfin.2014.06.001

De Jong, A., Kabir, R., \& Nguyen, T. T. (2007). Capital Structure around the World: The Roles of Firm-and Country-Specific Determinants ERIM Report Series reference number. Retrieved from www.erim.eur.nl

Fama, E. F., \& French, K. R. (2002). Testing Trade-Off and Pecking Order Predictions About Dividends and Debt. Review of Financial Studies, 15(1), 1-33. https://doi.org/10.1093/rfs/15.1.1

Fan, J. P. H., Titman, S., \& Twite, G. (2012). An international comparison of capital structure and debt maturity choices. Journal of Financial and Quantitative Analysis, 47(1), 23-56. https://doi.org/10.1017/S0022109011000597

Faulkender, M., \& Petersen, M. A. (2006). Does the source of capital affect capital structure? Review of Financial Studies, Vol. 19, pp. 45-79. https://doi.org/10.1093/rfs/hhj003 
Frank, M. Z., \& Goyal, V. K. (2009). Capital structure decisions: Which factors are reliably important? Financial Management, 38(1), 1-37. https://doi.org/10.1111/j.1755-053X.2009.01026.X

Gungoraydinoglu, A., \& Öztekin, Ö. (2011). Firm- and countrylevel determinants of corporate leverage: Some new international evidence. Journal of Corporate Finance, 17(5), 1457-1474. https://doi.org/10.1016/j.jcorpfin.2011.08.004

Han, S.-H., Kang, K., \& Shin, Y. S. (2016). Bond ratings, corporate governance, and cost of debt: The case of Korea. Journal of Asian Finance, Economics and Business, 3(3), 5-15. https://doi. org/10.13106/jafeb.2016.vol3.no3.5.

Hastie, T., Tibshirani, R., \& Friedman, J. (2001). The Elements of Statistical Learning: Data Mining, Inference, and Prediction. New York: Springer.

Hill, T. D., Davis, A. P., Roos, J. M., \& French, M. T. (2019). Limitations of Fixed-Effects Models for Panel Data. Sociological Perspectives, 073112141986378. https://doi. org/10.1177/0731121419863785

Javid, A. Y., \& Iqbal, R. (2008). Ownership Concentration, Corporate Governance and Firm Performance: Evidence from Pakistan. The Pakistan Development Review, Vol. 47, pp. 643659. https://doi.org/10.2307/41261245

Kabeer, M. A., \& Rafique, S. (2018). PP 1-16 Journal of Banking and Finance Management V1 • I3 •. In Journal of Banking and Finance Management (Vol. 1).

Kayo, E. K., \& Kimura, H. (2011). Hierarchical determinants of capital structure. Journal of Banking and Finance, 35(2), 358371. https://doi.org/10.1016/j.jbankfin.2010.08.015

Khalid, S. (2010). Financial Reforms and Dynamics of Capital Structure Choice: A Case of Publically Listed Firms of Pakistan. Journal of Management Research, 3(1), 3. https://doi. org/10.5296/jmr.v3i1.359

La Porta, R., Lopez-de-Silanes, F., \& Shleifer, A. (1999). Corporate ownership around the world. Journal of Finance, 54(2), 471517. https://doi.org/10.1111/0022-1082.00115

Mackie-Mason, J. K. (1990). Do Taxes Affect Corporate Financing Decisions? The Journal of Finance, 45(5), 1471-1493. https:// doi.org/10.1111/j.1540-6261.1990.tb03724.x

Matemilola, B. T., Bany-Ariffin,A. N.,Azman-Saini, W. N. W., \& Nassir, A. M. (2019). Impact of institutional quality on the capital structure of firms in developing countries. Emerging Markets Review, 39, 175-209. https://doi.org/10.1016/j.ememar.2019.04.003

Myers, S. C. (1984). The Capital Structure Puzzle. The Journal of Finance, 39(3), 574-592. https://doi. org/10.1111/j.1540-6261.1984.tb03646.x
Myers, S. C., \& Majluf, N. S. (1984). Corporate financing and investment decisions when firms have information that investors do not have. Journal of Financial Economics, 13(2), 187-221. https://doi.org/10.1016/0304-405X(84)90023-0

Nguyen, C. T., Bui, C. M., \& Pham, T. D. (2019). Corporate capital structure adjustments: Evidence from Vietnam stock exchange market. Journal of Asian Finance, Economics and Business, 6(3), 41-53. https://doi.org/10.13106/jafeb.2019.vol6.no3.41

Öztekin, Ö. (2015). Capital structure decisions around the world: which factors are reliably important? Journal of Financial and Quantitative, 50(3), 301-323. https://doi.org/10.1017/ S0022109014000660

Schwarz, G. (1978). Estimating the Dimension of a Model. The Annals of Statistics, 6(2), 461-464. https://doi.org/10.1214/ aos/1176344136

Shah, A., Khan, S., \& Khan, S. (2007). Determinants of Capital Structure: Evidence from Pakistani Panel Data. In International Review of Business Research Papers (Vol. 3). Retrieved from http://ssrn.com/abstract $=1027180$

Sheikh, N. A., \& Wang, Z. (2012). Effects of corporate governance on capital structure: Empirical evidence from Pakistan. Corporate Governance (Bingley), 12(5), 629-641. https://doi. org/10.1108/14720701211275569

Studenmund, A. H., \& Cassidy, H. J. (1992). Using Econometrics: A Practical Guide. Bostan, MA: Addison-Wesley Educational Publishers.

Stulz, R. M. (1990). Managerial discretion and optimal financing policies. Journal of Financial Economics, 26(1), 3-27. https:// doi.org/10.1016/0304-405X(90)90011-N

Vijayakumaran, S., \& Vijayakumaran, R. (2019). Corporate governance and capital structure decisions: Evidence from Chinese listed companies. Journal of Asian Finance, Economics and Business, 6(3), 67-79. https://doi.org/10.13106/jafeb.2019. vol6.no3.67

\section{Endnotes}

iPlease refer (Schwarz, 1978) for insightful understanding of BIC.

iiSTATA calculate these results with the iverg2, gmm2s robust command. For detail explanation refer (Baum, Schaffer, \& Stillman, 2003).

iiiFor instance, the mean value of MBR and A_grow of the Chinese listed firms reported by (Chang et al., 2014) are 2.416 and 0.14 respectively. 